ferous warts only about half the size of stigmata, very pale brown and polished, each supporting a fine hair of a faintly yellowish color, of which those on the posterior row of warts are much the longest and are directed forward. Similar long hairs are also on the head, thorax, around the margin of the anal plate and along the sides of the body. Legs concolorous with body.

Pupa.-Average length $7 \mathrm{~mm}$. Brownish-yellow. Stigmata brown. A dorsal, dark brown, transverse band, anteriorly on last joint. Tip broad, almost straight, having a small tooth at each angle, and along its inferior edge four fine yellowish-brown bristles, twisted and directed forward. Abdomen shallowly punctate.

In the series of American Phycids, this species naturally follows indiginella, and it is at once distinguished from this, from juglandis LeBaron, and from fallouella Ragonot-its nearest European ally-by the obsolescence of the triangular costal patch.

Mr. Grote in his last "Check list of N. A. Moths," has suppressed Acrobasis Zeller, and referred this little group of Phycids to "Phycis Haw." He has also made juglandis a variety of indiginella. These changes I regard as unjustifiable. Phycis as a genus was founded by Fabricius, and Haworth's Phycis comprised nearly all the species of the family, and the name has long been abandoned in modern more exact classifications; while the full descriptions, figures and larval histories of indiginella and juglandis in my $4^{\text {th }}$ Rep. on the Insects of Mo. (pp. 38-43) prove beyond all question the specific value of both.

There is a Nephopteryx vacciniella Zeller or Vaccinium uliginosum in Europe, and for this reason $I$ have dropped the conventional termination in the name of our species.

\title{
NOTE ON INEQUALITY OF THE ELYTRA IN ALAUS OCULATUS.
}

BY C. H. T. TOWNSEND, CONSTANTINE, Mich.

On I $9^{\text {th }}$ October, 1884 , I took from a decaying hickory stump a specimen of Alaus oculatus (Linn.), which had its left elytron $.75 \mathrm{~mm}$. shorter than its right. This seemed to me a curious and very noticeable deformity, and one I had never before observed. But on I $3^{\text {th }}$ December 
ensuing I discovered that a fine, robust specimen which I had taken from decaying hickory the day previous had its left elytron $.25 \mathrm{~mm}$. shorter than its right, this time the difference being much less, but still noticeable. I then examined fifteen other specimens of this species in my collection, with the following result: One with left elytron $.25 \mathrm{~mm}$. shorter than right; one with left .20 $\mathrm{mm}$. shorter than right; one with left shorter than right, but the difference hardly appreciable; one (small specimen) with right $.20 \mathrm{~mm}$. shorter than left; and one in which the right was so slightly less than the left that the difference could scarcely be seen. The remaining ten showed no appreciable differences in this respect. So of seventeen specimens examined, seven had the elytra unequal in length in a considerable degree, one being especially prominent thereby. And it is noticeable that in five of the seven specimens it was the left elytron that was the shorter, these also being the cases in which the inequality was most prominent. I believe all of my specimens, with one exception, were taken from their cells in the wood, as they are found after having assumed the imago. I have no doubt that if others would examine the specimens of this species in their collections, many more such examples would be found which have been overlooked. It would be interesting to know the result of such examinations. It is probable that the elytra, being organs not of strictly primary value to the insect-elytral invariability in this direction not being absolutely essential when within certain limits-have thus been permitted to vary without the variations being struck out by natural selection. I have not observed this elytral inequality in any other Coleoptera as yet.

A form of this species, which is less robust, I occasionally find; it is slightly narrower in proportion and more delicately marked, but upon sending specimens of the two to Dr. Horn, he informs me that they do not differ appreciably, but are both oculatus.

\section{CORRESPONDENCE.}

NOTE ON THE HABITAT OF XYLORYCTES SATYRUS.

Dear Sir: Mr. W. F. Robinson, of Bridgeton, N. J., sent, Oct. 28 , I 884 , a specimen of this beetle, with the remark that it is being dug up around the roots of trees there in abundance by his school boys. The collections here contain it not farther to the north than Pennsylvania. Not 